\author{
OSOBA | SAMOTNOŚĆ. MIĘDZY CODZIENNOŚCIĄ A MISTYKĄ \\ Filozofia ChrZeśCIJAŃSKa • TOM 12, Poznań 2015 \\ Uniwersytet im. Adama Mickiewicza w Poznaniu - Wydział Teologiczny \\ doi: $10.14746 /$ fc.2015.12.03
}

\author{
MAGDALENA BIZIOR-DOMBROWSKA \\ Uniwersytet Mikołaja Kopernika w Toruniu
}

\title{
Samotność i doświadczenie mistyczne
}

\author{
Solitude and Mystical Experience
}

Do mistycznych paradoksów - obok mistycznego poznania bez poznania i niewiedzy pojmowanej jako rodzaj najwyższej wiedzy ${ }^{1}$, ciemności zawierającej światło, wielości okazującej się utajoną jednością - można zaliczyć niewątpliwie problem relacji między jednostką a wspólnotą. Mistyk wydaje się swoistą monadą, odizolowaną od społeczeństwa, zamkniętą na świat materialny uznawany za źródło złych wpływów oraz przyczynę duchowego rozproszenia. Duchową siłę mistycy czerpią z samotności (która umożliwia stan skupienia wewnętrznego i mistyczną kontemplację), w separacji od innych, zgodnie ze sformułowanym przez Angelusa Silesiusa nakazem, aby ,wyrzec się wszystkiego, co nie jest podobne do Boga" ${ }^{\prime 2}$. Ich zdaniem, doświadczenie mistyczne ${ }^{3}$ nie może być udzia-

${ }^{1}$ Jak wskazuje Mistrz Eckhart, proces poznania to „zdejmowanie zasłon” - odrzucenie ograniczeń poznania pojęciowego, które ma prowadzić do poznania Boga jako niepoznanego - jako Ostatecznej Tajemnicy. Celem doświadczenia mistycznego nie jest zatem poznanie Boga, lecz dostąpienie łaski obecności Boga i zjednoczenie z Nim. W tym kontekście wiedza okazuje się ,świętą niewiedzą". Zob. J.A. Kłoczowski, Mistyka - między stowem a milczeniem, w: Mickiewicz mistyczny, red. A. Fabianowski i E. Hoffmann-Piotrowska, Warszawa 2005, s. 15.

${ }^{2}$ Zob. J. Tomkowski, Juliusz Słowacki i tradycje mistyki europejskiej, Warszawa 1984, s. 179.

${ }^{3}$ Doświadczenie mistyczne będzie tu zasadniczo analizowane w perspektywie mistyki chrześcijańskiej i rozumiane jako autentyczne doświadczenie religijne polegające na bezpośrednim doświadczeniu obecności Boga, który udziela się duszy w taki sposób, że daje się odczuć niejako „od wewnątrz" (zob. B. McGinn, Fundamenty mistyki, thum. T. Dekert, Kraków 2009, s. XVIII). W takim porządku można ujmować doświadczenie mistyczne jako doświadczenie wewnętrzne, podczas którego dochodzi do zawieszenia władz człowieka i doświadczenia Boga względem duszy transcendentnego i udzielającego się samorzutnie (zob. S. Urbański, Teologia życia mistycznego. Studium polskiej mistyki (1914-1939), Warszawa 1999, s. 190-235, 216-220). Problem samotności zostanie również omówiony w kontekście twórczości romantycznej - w tym ujęciu doświadczenie mistyczne należy odnieść do mistycznego doświadczenia jaźni, którego rdzeniem jest bezpośred- 
łem zbiorowości, stan najwyższego skupienia ducha osiaga się w odosobnieniu, niemożliwością wydaje się udzielenie innym cząstki boskiego światła spływającego na osobę mistyka. Stąd doświadczenie mistyczne uznaje się na ogół za jednostkowe, wymagające samotności. Pozostaje to w oczywistej sprzeczności z chrześcijańskim nakazem realizacji kodeksu wartości wobec wspólnoty łączącym się z najważniejszym przykazaniem miłości bliźniego. Z drugiej strony jednakże to właśnie $\mathrm{w}$ doświadczeniu mistycznym dokonuje się przecież przekroczenie samotności poprzez unię mistyczną ze stworzeniem. Mistyk osiąga stan, „w którym wszystko jest we mnie i ja we wszystkim", pogrążony w najgłębszej samotności, nie traci duchowej więzi ze światem. Powszechny wizerunek mistyka jako człowieka dążącego do stanu kompletnej izolacji, chroniącego się w pustelni, celi klasztornej, niechętnie przyjmującego obecność innych, nie do końca okazuje się prawdziwy. W rzeczywistości bowiem mistyk - mimo że pogrążony w samotności - nigdy nie jest sam. Jak zauważa Jacques Maritain, wszelka mistyka okazuje się sztuką dialogu - dialogu mistyka ze Stwórca, który nie przewiduje innych rozmówców i wymaga wyzwolenia się z zaklętego kręgu codzienności ${ }^{5}$. Historię mistyki europejskiej tworzą zatem samotnicy z wyboru, ale także z bolesnej konieczności wynikającej z niemożności porozumienia się ze wspólnotą 6 .

Łączy się z tym problem antynomii słowa i milczenia: tekst mistyczny okazuje się kolejnym paradoksem, gdyż jego przedmiotem jest to, co niewyrażalne, to, czego nie da się ująć w słowa. Nieopisywalność doświadczenia mistycznego prowadzi do tragicznej przepaści komunikacyjnej między mistykiem a innymi. Doświadczenie mistyczne wyznacza ostateczną granicę, poza którą jest już tylko milczenie - milczenie o Bogu, o którym nie można mówić, który pozostaje poza wszelkimi pojęciami i którego ludzki język nie jest w stanie wyrazić:

nie doświadczenie istnienia jaźni tożsamego z istnieniem Boga. Definiuje się je jako immanentne doznanie obecności Boga w podmiocie doznającym; specyficzny stan świadomego ujęcia przez podmiot obecności Boga wewnątrz człowieka, zainicjowany przez przyczynę wobec podmiotu zewnętrzną: Boga (L. Dupré, Inny wymiar, tłum. S. Lewandowska, Kraków 1991). Takie ujęcie wpisuje się w obszar zachodnioeuropejskich koncepcji podmiotu uznających, że doświadczenie mistyczne jest „ludzkim poznaniem Boga, jako Istnienia, poznaniem spowodowanym przez Boga dzięki Jego udostępnieniu się intelektowi człowieka bezpośrednio, bez rozumowań, bez pojęć, nagle i na chwilę" (M. Gogacz, Filozoficzne aspekty mistyki. Materiały do filozofii mistyki, Warszawa 1985, s. 56).

${ }^{4}$ M. Bierdiajew, Rozważania o egzystencji. Filozofia samotności i wspólnoty, thum. H. Paprocki, Kęty 2002, s. 70.

${ }^{5}$ Zob. J. Tomkowski, Mistyka i herezja, Ossa 2006, s. 38.

${ }^{6}$ Powrót mistyka do wspólnoty jest niezwykle trudny. Zasadniczym problem okazuje się niemożność odnalezienia wspólnego kodu komunikacyjnego. Doświadczenie mistyczne jest niewyrażalne, jego istotę stanowi milczenie, dlatego próby wyrażenia tego, co z istoty niewyrażalne, okazywały się często bolesne. Mistycy musieli się przede wszystkim zmagać z ograniczeniami ludzkiego języka, który okazywał się niewystarczający dla opisania doświadczenia mistycznego, np. Jan Tauler, kiedy po dwóch latach osamotnienia i ascezy wstapił na ambonę, nie potrafił powiedzieć ani słowa. Zob. J. Tomkowski, Mistyka i herezja, dz. cyt., s. 25. 
To miejsce (miejscem tym jest Bóg) pozostaje bez nazwy i nikt nie potrafi go określić właściwym mianem. Wszelkie słowo, jakie możemy o Nim powiedzieć, bardziej jest negacją wyrażająca, czym Bóg nie jest, aniżeli stwierdzeniem tego, czym jest. To właśnie podjął pewien boski mistrz, któremu się wydawało, że wszystko, co mógł wypowiedzieć o Bogu słowami zawierało jakieś elementy fałszu, a inaczej nie potrafiłby tego wyrazić. Dlatego też milczał i nie chciał powiedzieć ani jednego słowa, tak że inni mistrzowie naśmiewali się z niego. $Z$ tej przyczyny dużo lepiej jest zachować milczenie na temat Boga, aniżeli o Nim mówić

Jak wskazuje Mistrz Eckhart, doskonałe odosobnienie (które prowadzi do unii mistycznej) jest nieme, samo mówienie o nim unieważnia je i zanieczyszcza ${ }^{8}$.

W samotności i milczeniu ujawnia się ,najgłębszy sposób istnienia człowieka” - wewnętrzny wymiar nazwany przez Maxa Schelera „osobą intymną”, niedostępny dla wszelkiego współprzeżywania i współodczuwania. Właśnie w tej najgłębszej samotności człowiek otwiera się na obecność Boga. „Pustynia jest monoteistyczna: właśnie na pustyni ludzie odkrywali Boga, odkrywając wraz z nim najgłębszy wymiar swego osobowego bytu"'.

Milczenie i samotność okazują się niezbędnymi elementami konstytuującymi przestrzeń doświadczenia mistycznego. Mistyk opuszcza sferę słowa gwarantującego komunikację ze wspólnota, aby móc wkroczyć w przestrzeń milczenia i przejść przez kolejne etapy odosobnienia, umożliwiające pozbycie się wszelkich ograniczeń i prowadzące do duchowego oczyszczenia. Tylko w ten sposób może zostać zrealizowany cel drogi mistycznej: zjednoczenie z Bogiem. Wiedza o Bogu (który w doświadczeniu mistycznym jest poznany jako niepoznany i niewyrażalny) okazuje się niemożliwa do przekazania. Z drugiej strony mistyk czuje się przymuszony do głoszenia i tłumaczenia tajemnic Bożych, dlatego relacja między mistykiem a wspólnotą często sprowadza się do zawieszenia między milczeniem o niewyrażalnym a koniecznością głoszenia prawdy objawionej: „[...] mistyka nie obowiązuje żadna gramatyka wypowiedzi, rządzi nim natomiast, [...] paradoks wyrażania, który łączy przymus milczenia o kontakcie z Niewyrażalnym oraz konieczność wyrażenia, poświadczającego ów kontakt. Mistyk musi milczeć, ale milczeć nie może"10. Droga mistyka rozpoczyna się zatem od wycofania się ze słowa i wspólnoty, prowadzi poprzez samotność i milczenie gwarantujące komunikację z Bogiem, by zakończyć się powrotem do

\footnotetext{
${ }^{7}$ Mistrz Eckhart, Kazanie 83, cyt. za: J.. Piórczyński, Mistrz Eckhart. Mistyka jako filozofia, Wrocław 1997, s. 31.

${ }^{8}$ Zob. J. Piórczyński, Mistrz Eckhart, dz. cyt., s. 176-177.

9 J.A. Kłoczowski, Między samotnościq a wspólnotq. Wstęp do filozofii religii, Tarnów 1994, s. 10.

${ }^{10} \mathrm{~W}$. Gutowski, „I kto zagasit okropne świecidto?”. Semantyka ognia i światta w twórczości Juliusza Słowackiego, w: tenże, Pasje wyobraźni. Szkice o literaturze romantyzmu i Młodej Polski, Toruń 1991, s. 31.
} 
wspólnoty i próbą znalezienia języka, za pomocą którego będzie można wyrazić objawioną prawdę:

Mistyk uczestniczy w komunikacji międzyludzkiej i w kulturze poprzez słowo. Ale jego dążeniem jest wyrwanie się z tej sfery zapośredniczenia, aby uczestniczyć w bezpośrednim kontakcie z Bogiem. Mistyk zaczyna mówić przede wszystkim dlatego, że chce pouczyć swoich uczniów i adeptów. Nie chce trzymać swojej wiedzy pod korcem, bo nie pozwala mu na to miłość bliźniego, jakim przecież jest dla niego uczeńn ${ }^{11}$.

Jak pisze Jan Andrzej Kłoczowski, powołując się na badania z zakresu filozofii języka, język mistyka ma pełnić przede wszystkim funkcję perswazyjną mistyk ma wskazywać innym drogę przemiany i naprowadzać ich na sytuację religijnego otwarcia ${ }^{12}$. Głównym celem tekstu mistycznego ma być zatem „nie przekazywanie jakiejś konkretnej treści, lecz towarzyszenie czytelnikowi w nadziei na osiągnięcie przez niego świadomości Bożej obecności"13. Mistycy tworzyli własny język, który opisywał w sposób niebezpośredni niewysławialne doświadczenie mistyczne, a wobec wspólnoty pełnił funkcję transformacyjną.

Powyższe antynomie ujawniające się w doświadczeniu mistycznym konstytuują swoisty paradoks mistyczny, stanowiący jeden z największych dylematów mistyki odnoszący się do relacji między mistykiem a wspólnotą. Analiza poszczególnych typów samotności pojawiających się na różnych etapach doświadczenia mistycznego przynosi niezwykle znamienny obraz relacji między trzema biegunami: mistykiem, wspólnotą i Bogiem. Ich istotą okazuje się zawsze dialog, który nie pozwala nigdy utożsamić nawet najgłębszej samotności mistyka z izolacją od wspólnoty. Samotność mistyka to samotność duchowa, która „nie jest uchyleniem się od dialogu, lecz stanowi ostatnie jego słowo"14.

\section{WIERNA SAMOTNOŚĆ}

Samotność jest niezbędnym warunkiem modlitwy kontemplacyjnej, jaki odnajdujemy w pismach mistyków. Święty Jan od Krzyża, nawiązując do obrazu idealnej modlitwy, pojawiającego się w Ewangelii (odbywającej się zawsze w ukryciu, w miejscach samotnych, w cichej porze nocy) wskazuje trzy rodzaje miejsc świętych: krajobrazy rozbudzające pobożność (czego wzór odnajdujemy u pustelników i anachoretów), samotne miejsca, gdzie Bóg udziela łask duchowych, oraz miejsca czci Boga ${ }^{15}$. Obecność innych ludzi często uniemożliwia mo-

${ }^{11}$ J.A. Kłoczowski, Mistyka - między słowem a milczeniem, dz. cyt., s. 19.

12 Tamże, s. 20-22.

${ }^{13}$ B. McGinn, Fundamenty mistyki, dz. cyt., s. XVIII.

${ }^{14}$ J.A. Kłoczowski, Między samotnościq a wspólnota, dz. cyt., s. 9.

${ }^{15}$ Jan od Krzyża, Droga na Górę Karmel, w: tenże, Dzieła, tłum. o. B. Smyrak OCD, Kraków 1986, rozdz. 42, s. 389-391. 
dlitwę, ponieważ nie pozwala w pełni uwolnić się od zgiełku świata i osiagnąć stanu skupienia niezbędnego dla kontemplacji. Samotność jawi się jako przestrzeń graniczna, w której dokonuje się przejście od sfery zewnętrznej (w której funkcjonuje wspólnota) do wewnętrznej, duchowej. Dlatego św. Jan od Krzyża zaleca odbywanie modlitw i pielgrzymek w samotności:

Bardzo często udziela Bóg łask przez obrazy znajdujące się w miejscach ustronnych i samotnych. Bywa tak dlatego, że przez trud jakiego wymaga dojście na te miejsca, wzrasta uczucie i siła pobożności. Następnie dlatego, że ludzie usuwają się wtedy od zgiełku świata, aby się lepiej pomodlić, jak to czynił Pan nasz Jezus Chrystus. Kto więc odbywa pielgrzymkę dobrze czyni jeśli ją odbywa samotnie chociażby w innym, niż zwyczajny, czasie. Nigdy bym zaś nie radził podejmować wtedy pielgrzymki gdy idzie wielki thum ludzi. Wówczas bowiem ludzie wracają bardziej roztargnieni niż przedtem ${ }^{16}$.

Wielką pochwałę samotności odnajdujemy w Pieśni duchowej, gdzie zostaje ona utożsamiona $\mathrm{z}$ drogą do zjednoczenia z Bogiem. Samotność oznacza przede wszystkim przekroczenie ograniczeń świata zewnętrznego, ogołocenie z uzależnień, które pojawiają się zawsze, gdy człowiek funkcjonuje w relacjach z innymi. Tylko w samotności można osiagnąć prawdziwą wolność duchową, dlatego Jan od Krzyża pisze wprost o ukryciu w samotności, w której ma dokonać się otwarcie na obecność Boga. Samotność funkcjonuje tu na kilku poziomach: człowiek wkracza w przestrzeń samotności i opuszcza wspólnotę, aby otworzyć się na sferę duchowa, ale przyczyna tego tkwi także w samotności, jaką odczuwa we wspólnocie ten, który pragnie Boga: „Jeśli bowiem dusza pragnie Boga, żadne towarzystwo nie przynosi jej pociechy. I zanim nie znajdzie Boga, czuje coraz to większe osamotnienie"17. Droga mistyczna ma także nauczyć samotności we wspólnocie - samotności, która nie będzie źródłem cierpienia. W doświadczeniu mistycznym dokonuje się bowiem duchowe udoskonalenie duszy i ostateczne przekroczenie samotności.

Wierna samotność łączy się przede wszystkim z ideą anachorezy: życia odosobnionego na pustyni, mającego służyć odsunięciu się od świata zewnętrznego, kontemplacji, otwarciu się na sprawy duchowe i poznaniu Boga. O anachorezie należy mówić w dwóch porządkach: zewnętrznym, gdzie anachoreza oznacza odosobnienie, przebywanie $z$ dala od ludzi, separację od społeczeństwa, oraz w porządku wewnętrznym, duchowym sprowadzającym ją do wyrzeczenia się namiętności związanych ze światem zewnętrznym ${ }^{18}$. Anachoreta rezygnuje

${ }^{16}$ Tamże, ks. III, rozdz. 36, 3.

${ }^{17}$ Jan do Krzyża, Pieśń duchowa, w: tenże, Dzieła, dz. cyt., strofa 35, objaśnienie, s. 687.

${ }^{18} \mathrm{~W}$ tych dwóch wymiarach ujmował anachorezę Ewagriusz z Pontu, dostrzegając jednocześnie pewną dwuwarstwowość w pojęciu separacji anachorety od świata: „Pojęcie owej separacji odnosił do świata zewnętrznego, rozumiejąc je jako opuszczenie przez ascetę swoich stron, rodziny, bliskich, oraz wiązał je ze światem wewnętrznym, duchowym, istniejącym w samym anachore- 
z życia w społeczeństwie, opuszcza świat zewnętrzny, aby móc istnieć w świecie wewnętrznym, w rzeczywistości ducha i prawdy. Oddalenie od świata stwarza korzystne warunki dla wyciszenia umysłu, ponieważ człowiek żyjący w świecie ulega rozproszeniu i uzależnia się od ludzi i rzeczy rodzących pragnienia. Izolacja nie jest jednakże celem sama $\mathrm{w}$ sobie, jest jedynie środkiem do osiagnięcia wewnętrznego stanu skupienia umożliwiającego kontemplację. Ostatecznym zaś celem odosobnienia i wyrzeczenia się świata ma być, jak wskazuje Ewagriusz z Pontu, zdobycie światła wewnętrznego rozeznania oraz osiagnięcie stanu beznamiętności ${ }^{19}$.

Co znamienne, anachoreza nie oznacza całkowitej separacji od wspólnoty. Jeden z najsłynniejszych ojców pustyni, Ewagriusz z Pontu (który spędził na egipskiej pustyni 16 lat, ale nie w absolutnej separacji od ludzi; jego pustelnia oznaczała dom, w którym mieszkał ze swoimi uczniami i który był odwiedzany przez gości z zewnątrz ${ }^{20}$ ) przestrzegał przed wypaczeniami idei życia pustelniczego, dostrzegając pozytywne aspekty spotkań z ludźmi - ale tylko wtedy, gdy były one pożyteczne duchowo i nie odrywały pustelnika od spraw duchowych. Natomiast rezygnacji z kontaktów z ludźmi - stanowiącymi duchowe zagrożenie i wprowadzającymi rozproszenie - wymaga realizacja idei hezychii oznaczającej stan wewnętrznego skupienia, który osiagga się poprzez przebywanie w celi i ciszy. Ewagriusz nazywa ten stan wierną samotnością, tożsamą z permanentnym trwaniem w ciszy, kontemplacją, „samotnym wnikaniem w swoje wnętrze”. Wierne pozostawanie w samotności (stanie wewnętrznego skupienia) wyklucza spotkania z ludźmi, którzy odrywają od kontemplacji i wprowadzają rozproszenie. Należy pamiętać jednakże, że Ewagriusz wyznacza także pewne granice trwania w idealnym odosobnieniu. Hezychia powinna być bowiem podporządkowana właściwie pojętej zasadzie miłości bliźniego. Niekiedy wyższe dobro wymaga rezygnacji z odosobnienia - najlepiej wyjaśnia tę zasadę kwestia odwiedzin innych mnichów, w których anachoreta powinien dostrzegać samego Boga, a nie - przeszkodę w realizowaniu idei hezychii ${ }^{21}$. Anachoreza okazuje się zatem przede wszystkim procesem duchowym, a monastyczna anachoreza na pustyni stanowi jedynie jej cielesny symbol. Bez wątpienia jednakże anachoreza wpisuje

cie. W tym drugim rozumieniu nie chodzi o jakieś wyjście, wycofanie się z jednej rzeczywistości do drugiej, ale o przebywanie w istniejącym duchowo świecie. Przebywanie to zakłada jednak pewną separację - w tym sensie, że wejście w świat ducha, powrót do własnego ja, wymaga wycofania się z rzeczywistości zewnętrznej” - L. Nieścior, Anachoreza w pismach Ewagriusza z Pontu, Kraków 1997, s. 42.

${ }^{19}$ Tamże, s. 44.

${ }^{20} \mathrm{~W}$ osadzie Cele, gdzie przebywał Ewagriusz, mieszkało około 600 anachoretów żyjących w niewielkim oddaleniu od siebie (tak, żeby nie mogli się nawzajem słyszeć). Ojcowie pustyni często się odwiedzali, aby zasięgnąc rady, aby się wspierać duchowo, gdy przestawali widzieć przejrzyście. Ponadto dziennie Ewagriusza odwiedzało około pięciu przybyszów z zewnątrz. Zob. L. Nieścior, Wstęp, w: Ewagriusz z Pontu, Pisma ascetyczne, t. 1, tłum. K. Bielawski, M. Grzelak, E. Kędziorek, L. Nieścior, A. Ziernicki, Kraków 1999, s. 19-23.

${ }^{21}$ L. Nieścior, Anachoreza, dz. cyt., s. 90. 
się w przestrzeń doświadczenia mistycznego, stając się niezbędnym warunkiem duchowego skupienia i ważnym elementem duchowej drogi ku poznaniu Boga. Anachoreza umożliwia kontemplację i modlitwę, jest wstępem do doświadczenia mistycznego (mistycznego zjednoczenia z Bogiem na drodze kontemplacji). Odsunięcie się od ludzi jest dla mistyka bezwzględnie konieczne, tylko w ten sposób może on osiagnąć stan ogołocenia się z wszelkich pragnień i myśli uniemożliwiających czystą modlitwę ${ }^{22}$.

Wierna samotność anachorety nie oznacza zatem ucieczki od świata jako takiego, lecz próbę uwolnienia się od jego wpływu na własne myślenie, na własne ja. To właśnie w doświadczeniu mistycznym dokonuje się przekroczenie samotności, mistyk nie jest już odosobnioną jednostką, lecz kimś doskonale zjednoczonym ze światem ${ }^{23}$. Tak więc, będąc od wszystkiego oddzielony, jest jednocześnie ze wszystkim harmonijnie zjednoczony, „uważa się za jedno ze wszystkimi, ponieważ nieustannie mu się zdaje, że dostrzega się w każdym innym" ${ }^{24}$. Mistyk nie jest już z tego świata, ale wciąż pozostaje światu bliski. Tak pojęta samotność nie prowadzi do zanegowania świata, lecz - poprzez oczyszczenie duchowe i pozbycie się fałszywego obrazu siebie - umożliwia powrót do świata, a w dalszej kolejności - jego uzdrowienie, odmienienie. Biografie wielkich mistyków potwierdzają ich ogromny wpływ na losy nie tylko wspólnoty religijnej, ale także historii. Mistycy za cel ostateczny stawiali sobie zawsze duchowe uzdrowienie wspólnoty, dlatego trzeba także mówić o konsekwencjach doświadczenia mistycznego sprowadzających się najczęściej do duchowej transformacji świata. W takim ujęciu samotność mistyczna jawi się jako przeciwieństwo samotności romantycznej - rozumianej przede wszystkim jako ucieczka od godnego pogardy świata, zaprzeczenie realności istnienia prowadzącej do wyobcowania jednostki. Istotę światopoglądu romantycznego stanowiło przekonanie o nieprzystawalności dwóch światów: zewnętrznego i wewnętrznego, prowadzące do tragicznego rozdarcia i zawieszenia. Romantyk negował rzeczywistość, uznając jedynie własne życie wewnętrzne za autentyczne. Rzeczywistość niedorastająca do jego marzeń stawała się często w jego przekonaniu miejscem bezwartościowym, dlatego chronił się przed nią w samotności, którą należy utożsamić z aktem negacji świata. Jej konsekwencją najczęściej okazywała się choroba woli prowadząca do całkowitego wycofania się z życia i niezdolności czynu. W samotności romantycznej dochodziło do „rozdęcia ja”, co prowadziło często do niemożności odnalezienia sensu w świecie zewnętrznym ${ }^{25}$. Samotność mistyka natomiast poprzez doświadczenie wewnętrz-

${ }^{22}$ Tamże, s. 181.

${ }^{23}$ G. Bunge, Acedia, duchowa depresja. Nauka duchowa Ewagriusza z Pontu o acedii, thum. J. Bednarek i A. Ziernicki, Kraków 2007, s. 62.

${ }^{24}$ Ewagriusz z Pontu, O modlitwie, tłum. K. Bielawski, w: tenże, Pisma ascetyczne, t. 1, dz. cyt., s. 125.

${ }^{25}$ Zob. M. Piwińska, Złe wychowanie, Gdańsk 2005, s. 121. 
ne (które jest tak naprawdę przekroczeniem siebie w stronę Boga) i zewnętrzne oddzielenie od innych okazuje się naturalnym środowiskiem poznania, umożliwiającym spojrzenie na świat $\mathrm{z}$ duchowej perspektywy.

Niezwykle interesująco przedstawia się kwestia samotności w kontekście integralnie z nią związanej acedii - rodzącej się w samotności atonii duszy, stanowiącej największe zagrożenie dla samotnego ascety. Oznaczała ona zarówno stan letargu i niezdolności do działania duchowego, jak i stan niepokoju wynikający z przekonania, że w innym miejscu nasze życie byłoby spełnione, z potrzeby bycia gdzie indziej oraz ze wstrętu do tu i teraz. Ten, kto ulega acedii, nienawidzi tego, co jest, pożąda zaś tego, czego nie $\mathrm{ma}^{26}$. Największy teoretyk acedii, Ewagriusz z Pontu wskazuje na jej trzy główne objawy: wewnętrzny niepokój (który nie pozwala skupić się na żadnej wykonywanej czynności i owocuje pokusą zmiany - zmiany prowadzącej jednakże donikąd, bo jedynie zaciemniającej nam prawdę o własnym bałaganie wewnętrznym), nienawiść do swojego życia (postrzeganie go jako monotonii i rutyny) oraz przekonanie o własnej samotności, opuszczeniu przez wszystkich, braku bliskości z innymi, niemożności uzyskania pocieszenia i wsparcia ${ }^{27}$. Demon acedii, określany przez Ewagriusza z Pontu jako najuciążliwszy spośród wszystkich demonów, przeobraża celę mnicha $\mathrm{w}$ egzystencjalne więzienie, zaciemnia jego relacje z Bogiem i skazuje na nieprzekraczalną samotność:

Nachodzi mnicha koło godziny czwartej i osacza jego duszę aż do godziny ósmej. Najpierw sprawia, że słońce zdaje się poruszać zbyt wolno lub wręcz nie porusza się wcale, a dzień tak się dłuży, jakby miał pięćdziesiąt godzin. Następnie przymusza mnicha, aby ciaggle wyglądał przez okno i wybiegał z celi, by wpatrywać się w słońce [...]. Wzbiera w nim wreszcie nienawiść do miejsca, w którym mieszka, do życia i do ręcznej pracy. I podsuwa myśl, że zanikła miłość wśród braci, a nie ma nikogo, kto by pocieszy ${ }^{28}$.

Acedia prowadzi często do odmowy uczestniczenia w świecie, który jawi się jako miejsce pozbawione wartości, do odrzucenia wizji historii pojętej jako celowy projekt, a w rezultacie: do odrzucenia Bożej miłości. Świat cierpiącemu na

\footnotetext{
${ }^{26}$ Acedia (gr. akēdia - 'beztroska, obojętność') jest terminem wieloznacznym, w tradycji chrześcijańskiej oznacza stan duchowego zobojętnienia, wypalenia religijnego. Święty Nil z Ancyry utożsamiał ją z chorobą objawiającą się niemożnością skupienia się na jednej rzeczy i znienawidzeniem swojego życia. Jan Kasjan łączył acedię z horror loci - przerażeniem miejscem, w którym się jest, oraz z niezdolnością do działania duchowego wynikającą z przekonania o bezsensowności istnienia. Szczegółową teorię acedii opracował Ewagriusz z Pontu, który umieścił ją wśród ośmiu złych myśli sprawczych, obok obżarstwa, nieczystości, chciwości, smutku, gniewu, próżności i pychy. Zob. G. Bunge, Acedia, dz. cyt., s. 25-62; M. Bieńczyk, Acedia, w: tenże, Melancholia. O tych, co nigdy nie odnajda straty, Warszawa 1998, s. 97-107.

${ }^{27}$ Zob. G. Bunge, Acedia, dz. cyt., s. 81-108.

${ }^{28}$ Ewagriusz z Pontu, O praktyce ascetycznej, tłum. E. Kędziorek, w: tenże, Pisma ascetyczne, dz. cyt., t. 1 , s. 12 .
} 
acedię wydaje się miejscem pozbawionym obecności Boga, a sam Bóg - jedynie pustym słowem, które straciło wszelkie znaczenie:

Co z kolei mam powiedzieć o demonie, który czyni duszę nieczułą? Boję się nawet pisać o nim: jak dusza wyobcowuje się z własnego stanu w czasie jego przybycia i pozbawia się bojaźni Bożej oraz pobożności, i nie uznaje już grzechu za grzech, i nie uważa nieprawości za nieprawość. W jej pamięci kara i sąd wieczny są już tylko gołymi słowami [...]. Wprawdzie niby wyznaje Boga, jednak nie poznaje jego zarządzenia. Uderzasz się w piersi, kiedy dusza zwraca się do grzechu, a ona nie czuje. Cytujesz słowa Pism, a ona jest całkiem zatwardziała i nawet nie słyszy ${ }^{29}$.

W ten sposób acedia zapoczątkowuje proces odrealnienia Boga:

Acedia jest więc sytuacją, w której Bóg przestaje być realny i zamienia się w martwą ideę, w zwykłe słowo (retoryczną figurę), które nie budzi już emocji i nie przekłada się w żaden sposób na kształt życia. Wszelkie działania, które miały człowieka wiązać $\mathrm{z}$ transcendencją i eschatologicznymi obietnicami jawią się teraz jako bezsensowne ${ }^{30}$.

Co znamienne, na acedię cierpią zarówno anachoreci, jak i cenobici. Acedia okazuje się ściśle związana z ludzką kondycją, może przybierać różne formy, w wersji zsekularyzowanej objawia się pod postacią nudy (zniechęcenia, zwątpienia w autentyczność naszego wyboru określonego sposobu życia, przekonania o bezwartościowości świata, niepokoju zmuszającego do zagłuszania pustki środkami doraźnymi: rozrywka, podróżami, życiem towarzyskim, co powoduje jedynie przesunięcie problemu i odwrócenie uwagi). Jak twierdził Pascal, nuda jest konsekwencją samotności, wyłania się z poczucia nicości, w jaką wpada człowiek w chwili, gdy pojawia się w jego życiu cisza, której nie zagłusza hałas codzienności: „Nie ma dla człowieka nic równie nieznośnego, jak zażywać pełnego spoczynku, bez namiętności, bez spraw, rozrywek, zatrudnienia. Czuje wówczas swoją nicość, opuszczenie, niewystarczalność, zależność, niemoc, próżnię. Bezzwłocznie wyłoni się z głębi jego duszy nuda, melancholia, smutek, troska, żal, rozpacz"31.

Jednocześnie jednakże przebywanie wśród ludzi wcale przed nudą nie chroni: wśród różnych rodzajów nudy można przecież odnaleźć obok nudy samotności (pojawiającej się w przestrzeni pozbawionej obecności Innego) także nudę towarzyską, rodzącą się w przestrzeni bez samotności lub miejscu przebywania z tymi samymi ludźmi ${ }^{32}$.

${ }^{29}$ Ewagriusz z Pontu, O różnych rodzajach zlych myśli, thum. L. Nieścior, w: tenże, Pisma ascetyczne, t. 1, Kraków 2007, s. 372.

${ }^{30}$ P. Kaznowski, Krótka historia metafizycznego znużenia, „Christianitas” 2010, nr 44, s. 53.

${ }^{31}$ B. Pascal, Myśli, tłum. T. Żeleński (Boy), Warszawa 1997, s. 95, 201 [47].

${ }^{32}$ Michał Paweł Markowski w szkicu $O$ nudzie wyodrębnił cztery najważniejsze kategorie nudy, jakie ukształtowały się w literaturze do końca XVIII wieku: nudę metafizyczną (świat bez Boga lub świat wyłącznie z ludzkimi pragnieniami), nudę towarzyską (świat bez samotności lub 


\section{ŚWIĘTA SAMOTNOŚĆ}

W projekcie drogi na Górę Karmel, czyli Drogi Doskonałości Duchowej św. Jana od Krzyża (której celem ma być transformacja duchowa i zjednoczenie duszy z Bogiem - zjednoczenie przekształcające), samotność okazuje się trwałym stanem duchowym. Kolejne etapy ścieżki mistycznej mają prowadzić do ogołocenia duszy: zerwania więzi ze światem zewnętrznym i swoim ja. Pierwszy etap, noc czynna zmysłów, podczas którego następuje wprowadzenie w stan kontemplacji, ma doprowadzić do wyrzeczenia się wszystkich rzeczy związanych ze światem, co umożliwi uwolnienie duszy od pożądań zmysłowych. Należy odrzucić skłonności uczuciowe do innych stworzeń i wyzbyć przywiązania do innych, ponieważ skłaniając się uczuciowo do innego człowieka, oddalamy się od Boga ${ }^{33}$, „dusza kochająca coś poza Bogiem czyni się niezdolną do przeobrażenia i czystego zjednoczenia z Nim" "34. Bliska relacja z drugim człowiekiem może okazać się poważną przeszkodą na drodze ku przeobrażeniu duchowemu. Dlatego św. Jan od Krzyża zaleca trwanie w św i ę tej s a motn ości: „Znam wiele osób, które jednak przez drobne przywiązania pod pokrywką jakiegoś dobra, towarzystwa czy przyjaźni pozbawiły się ducha i smaku Bożego świętej samotności i w końcu doszły do utraty wszystkiego” ${ }^{35}$. „Wąska ścieżka ciemnej kontemplacji” oznacza trwanie w s a motności dla Boga, bo „gdy dusza zajmie czymś wolę, nie będzie tak wolna, samotna i czysta, jak to jest konieczne do owego boskiego przeobrażenia"36. Kolejne etapy drogi mistycznej (podczas których dokonuje się oczyszczenie sfery duchowej od rozumu oraz pamięci i woli) są również wyznaczane przez samotność umożliwiającą ogołocenie i prowadzącą do stanu mistycznej próżni. Mistyczna s a motność dla Boga i w Bo$\mathrm{g} \mathrm{u}$ łączy się z koniecznością eliminacji własnej osobowości, jej ograniczania, a nawet unicestwienia, gdyż, jak wskazuje Jan Tauler, w objawieniu zostaje zniszczone wszystko, co nie jest samym Bogiem. Według założeń teologii mistycznej łaska kontemplacji mistycznej, tajemna wiedza o Bogu, którą najpełniej oddaje pojęcie promienia ciemności (sformułowane przez św. Dionizego Areopagitę), jest udzielana w ,piwnicy duchowej”, gdzie dusza pogrąża się w milczeniu i ciszy. Doskonale oddają to słowa Jakuba Böhmego: „Gdy znikniesz w sobie dla woli i zmysłów własnego ja, wówczas wieczysty słuch, wzrok i mowa otworem ci będą i zobaczysz i usłyszysz Boga poprzez siebie samego" ${ }^{37}$.

świat z tymi samymi ludźmi), nudę samotności (świat bez Innego) oraz nudę komunikacyjno-literacką (świat bez fikcji lub świat z jedną totalną opowieścią). M.P. Markowski, O nudzie, w: tenże, Anatomia ciekawości, Kraków 1999, s. 183-184.

${ }^{33}$ Jan od Krzyża, Droga na Góre Karmel, ks. I, rozdz. 5, 1, s. 141.

${ }^{34}$ Tamże, ks. I, rozdz. 4, 3, s. 138.

${ }^{35}$ Tamże, ks. I, rozdz. 11, 5, s. 162.

${ }^{36}$ Tamże, ks. I, rozdz. 11, 6, s. 163.

${ }^{37}$ J. Böhme, De Vita Mentali, cyt. za: J. Tomkowski, Mistyka i herezja, dz. cyt., s. 14. 


\section{SAMOTNOŚĆ WEWNĘTRZNA}

Samotność odgrywa zatem zasadniczą rolę na wszystkich etapach doświadczenia mistycznego: najpierw jawi się jako niezbędny warunek kontemplacji i oznacza w głównej mierze izolację od ludzi i świata zewnętrznego. Na kolejnych etapach przekształca się w trwały stan duchowy, gdzie należy mówić przede wszystkim o samotności wewnętrznej. Jej istotę doskonale wyraża Mistrz Eckhart, którego mistykę opisywano często jako mistykę odosobnienia, gdyż właśnie na konieczności separacji od wszelkiego ziemskiego przywiązania opiera się droga do osiagnnięcia wolności i znalezienia Boga ${ }^{38}$. Odosobnienie Eckharta oznacza przede wszystkim odcięcie się, oddzielenie, wyrzeczenie, zrezygnowanie z rzeczy doczesnych, jednakże pojęcie to nie ogranicza się jedynie do negatywnego ogołocenia, lecz obejmuje także pozytywne zwrócenie się do Boga. Odosobnienie ma dla Eckharta decydujące znaczenie, ale rozumiane nie jako zewnętrzne oddalenie się od ludzi, lecz jako oderwanie się od wszystkich stworzeńn ${ }^{39}$. W metafizyczno-etyczno-mistycznym projekcie opuszczenia wszystkiego i wyrzeczenia się siebie chodzi przede wszystkim o pokonanie własnego ja, aby móc patrzeć na świat, dostrzegając w nim nie siebie, lecz Boga.

Człowiek, który w ten sposób trwa w pełnym odosobnieniu, zostanie uniesiony aż do wieczności, do tego stopnia, że odtąd nie będzie go mogła poruszyć żadna rzecz doczesna, nie będzie odczuwał nic cielesnego, będzie jakby umarły dla całego świata, bo nic, co ziemskie mu nie smakuje [...] To nieporuszone odosobnienie najbardziej upodabnia człowieka do Boga ${ }^{40}$.

Projekt „,człowieka wewnętrznego” i związany z nim postulat wymiany ludzkiego na boskie w życiu wewnętrznym stanowi podstawę etyki ontycznej Eckharta.

Eckhart wyraźnie przeciwstawia samotności zewnętrznej samotność wewnętrzną (duchową, mistyczną), twierdząc, że uciekanie na pustynię nic nie da, jeśli nie nauczymy się znajdywać pustelni w sobie samym. Nad życie pustelnicze, porzucenie towarzystwa ludzi i samotność zewnętrzną przedkłada samotność wewnętrzna, którą należy znajdować w sobie w każdym miejscu: „Nie można się tego nauczyć przez ucieczki, przez to, że człowiek będzie unikał rzeczy i szukał zewnętrznie rozumianej samotności. Musi raczej nauczyć się szukania samotności wewnętrznej i znajdywania jej w każdym miejscu i towarzystwie"41.

Człowiek wewnętrzny ma dążyć do najgłębszego odosobnienia - to znaczy kierować się ku temu, co boskie, ku temu, co jest czystym milczeniem, w któ-

${ }^{38}$ Zob. B. McGinn, Mistyczna myśl Mistrza Eckharta, tłum. S. Szymański, Kraków 2009, s. 136 .

${ }^{39}$ Zob. W. Szymona, Wstęp, w: Mistrz Eckhart, Traktaty, thum. W. Szymona, Poznań 1987, s. 13.

${ }^{40}$ Mistrz Eckhart, $O$ odosobnieniu, w: tenże, Traktaty, dz. cyt., s. 157.

${ }^{41}$ Tenże, Pouczenia duchowe, w: tenże, Traktaty, dz. cyt., s. 26. 
rym następuje „całkowite upodobnienie się do Boga”42. W tym ujęciu samotność należy rozpatrywać w perspektywie etycznej, tzn. jako określoną postawę wyrzeczenia się pragnień związanych ze światem doczesnym. W takim rozumieniu staje się ona ważnym elementem projektu człowieka wewnętrznego. Eckhart uznawał odosobnienie za najwyższą cnotę, a „pustynię wewnętrzną" - za najdoskonalszy stan i cel bytu ludzkiego ${ }^{43}$.

Samotność wewnętrzna jest zatem stanem umożliwiającym kontemplację (proces inteligibilnego wchodzenia w sferę sacrum) mogącą prowadzić do doświadczenia mistycznego, nie wyklucza ona jednak możliwości pozostawania we wspólnocie ludzkiej. Znamienne tego przykłady odnajdziemy nie tylko w biografii wielkich mistyków, ale także wśród pisarzy realizujących mistyczny projekt uprawiania twórczości, do których możemy zaliczyć np. Juliusza Słowackiego czy Franza Kafkę. Kafka, na co dzień pracownik Zakładu Ubezpieczeń Robotników od Wypadków Królestwa Czeskiego w Pradze, traktował swoje pisarstwo jako formę modlitwy (notabene był zafascynowany mistycznymi elementami chasydyzmu), w samotności wewnętrznej widział niezbędny warunek twórczości:

Do mojego pisania potrzebuję zupełnego odosobnienia, nie takiego jak pustelnik, to nie byłoby wystarczające, lecz jak umarły. Pisanie tak rozumiane jest snem głębszym od snu, a więc śmiercią, i tak jak umarłego nie będzie się wyciągać i nie można wyciagać $\mathrm{z}$ jego grobu, tak też mnie nie można w nocy odciagnąć od mojego biurka ${ }^{44}$.

Analizując teksty Słowackiego, pochodzące z tzw. okresu mistycznego (zarówno teksty literackie, filozoficzne i osobiste - listy, dzienniki, notatki - które poeta $\mathrm{w}$ ostatnich latach życia traktował jako swoistą całość, w jakiej prezentował objawioną mu, jego zdaniem, tajemnicę), trzeba mieć świadomość, że poruszamy się w przestrzeni stanowiącej pogranicza mistyki, literatury i filozofii. Późna twórczość autora Genezis z Ducha stanowi pewien eksperyment myślowy i poetycki, realizowany przez dzieła fragmentaryczne i wariantowe, które należy traktować jako zapis procesu twórczego kształtowanego na podobieństwo tekstu świętego. Doznawane wizje nie odcinały jednakże poety od świata: kontaktów z ludźmi czy gry na giełdzie. Pytanie o to, czy mistyk może grać na giełdzie, ściśle się łączy z pytaniem o mistyczny czy mistycyzujący charakter utworów pochodzących z ostatniego etapu twórczości Słowackiego. Pozostanie ono na zawsze kwestią otwarta, podobnie jak pytanie o prawdziwość doświadczenia mistycznego - które jako doświadczenie wewnętrzne może być oceniane jedynie z perspektywy przeżywającego je podmiotu.

${ }^{42}$ Tamże, s. 163.

${ }^{43}$ Zob. J. Piórczyński, Mistrz Eckhart. Mistyka jako filozofia, dz. cyt., s. 174.

${ }^{44}$ F. Kafka, List do Felicji Bauer z 26 czerwca 1913 roku, w: tenże, Listy do Felicji, thum. I. Krońska, Warszawa 1976, s. 432. 


\section{BIBLIOGRAFIA}

Bieńczyk M., Acedia, w: tenże, Melancholia. O tych, co nigdy nie odnajda straty, Warszawa 1998, s. 97-107.

Bierdiajew M., Rozważania o egzystencji. Filozofia samotności i wspólnoty, tłum. H. Paprocki, Kęty 2002.

Bunge G., Acedia, duchowa depresja. Nauka duchowa Ewagriusza z Pontu o acedii, thum. J. Bednarek i A. Ziernicki, Kraków 2007.

Ewagriusz z Pontu, O modlitwie, tłum. K. Bielawski, w: tenże, Pisma ascetyczne, t. 1, Kraków 2007, s. 275-308.

Ewagriusz z Pontu, O praktyce ascetycznej, tłum. E. Kędziorek, w: tenże, Pisma ascetyczne, t. 1, Kraków 2007, s. 225-258.

Ewagriusz z Pontu, O różnych rodzajach złych myśli, tłum. L. Nieścior, w: tenże, Pisma ascetyczne, t. 1, Kraków 2007, s. 361-408.

Gutowski W., „I kto zagasił okropne świecidło?”. Semantyka ognia i światła w twórczości Juliusza Słowackiego, w: tenże, Pasje wyobraźni. Szkice o literaturze romantyzmu i Młodej Polski, Toruń 1991, s. 31-44.

Dupré L., Inny wymiar, tłum. S. Lewandowska, Kraków 1991.

Gogacz M., Filozoficzne aspekty mistyki. Materiały do filozofii mistyki, Warszawa 1985.

Jan od Krzyża, Droga na Górę Karmel, w: tenże, Dzieła, tłum. B. Smyrak, Kraków 1986, s. 123-398.

Jan od Krzyża, Pieśń duchowa, w: tenże, Dzieła, tłum. B. Smyrak, Kraków 1986, s. 523-714 .

Kaznowski P., Krótka historia metafizycznego znużenia, „Christianitas” 2010, nr 44, s. 40-57.

Kafka F., Listy do Felicji, tłum. I. Krońska, Warszawa 1976.

Kłoczowski J.A., Mistyka - między słowem a milczeniem, w: Mickiewicz mistyczny, red. A. Fabianowski i E. Hoffmann-Piotrowska, Warszawa 2005, s. 11-22.

Kłoczowski J.A., Między samotnościa a wspólnota. Wstęp do filozofii religii, Tarnów 1994.

Markowski M.P., O nudzie, w: tenże, Anatomia ciekawości, Kraków 1999, s. 158-184.

McGinn B., Mistyczna myśl Mistrza Eckharta, tłum. S. Szymański, Kraków 2009.

McGinn B., Fundamenty mistyki, tłum. T. Dekert, Kraków 2009.

Mistrz Eckhart, O odosobnieniu, w: tenże, Traktaty, tłum. W. Szymona, Poznań 1987, s. 147-152.

Mistrz Eckhart, Pouczenia duchowe, w: tenże, Traktaty, thum. W. Szymona, Poznań 1987, s. 17-70.

Nieścior L., Anachoreza w pismach Ewagriusza z Pontu, Kraków 1997.

Nieścior L., Wstęp, w: Ewagriusz z Pontu, Pisma ascetyczne, t. 1, tłum. K. Bielawski, M. Grzelak, E. Kędziorek, L. Nieścior, A. Ziernicki, Kraków 1999, s. 11-50.

Pascal B., Myśli, tłum. T. Żeleński (Boy), Warszawa 1997. 
Piórczyński J., Mistrz Eckhart. Mistyka jako filozofia, Wrocław 1997.

Piwińska M., Złe wychowanie, Gdańsk 2005.

Szymona W., Wstęp, w: Mistrz Ekchart, Traktaty, tłum. W. Szymona, Poznań 1987, s. 9-16.

Tomkowski J., Juliusz Stowacki i tradycje mistyki europejskiej, Warszawa 1984.

Tomkowski J., Mistyka i herezja, Ossa 2006.

Urbański S., Teologia życia mistycznego. Studium polskiej mistyki (1914-1939), Warszawa 1999.

\section{SUMMARY}

The article is an attempt of analysis of the category of loneliness in the mystical experience. The loneliness is a natural space of cognition and a necessary condition of the contemplation enabling the experience of God, but it is also irremovable element of all stages of the mystical experience. Three of the principle problems of this question were subjected to the analysis. Faithful loneliness constituting the essence of the concept of anachorese. From such point of view the isolation from the world (as well as the escape from the body) turns out to be a way to experience of God. Holy loneliness as a durable spiritual state connected with narrow path of the dark contemplation of St. John of the Cross (mystical loneliness in God and for God). Inner loneliness (Eckhart's seclusion as a basis of the project of inner man).

\section{Keywords}

mysticism, mystical experience, loneliness (faithful, holy, inner), seclusion, separation, contemplation, acedia

\section{Słowa kluczowe}

mistyka, doświadczenie mistyczne, samotność (wierna, święta, wewnętrzna), odosobnienie, separacja, kontemplacja, acedia 